\title{
Occurrence of Thraustochytrids on fallen mangrove leaves from Pagbilao Mangrove Park, Quezon Province
}

\author{
Justine Grace A. Perez ${ }^{1}$, Arlice Kristel A. Mappala ${ }^{1}$, Cendrix Kyle L. Icaro ${ }^{1}$, Ana Marinella T. Estrada ${ }^{1}$, \\ Kim Hazel V. Arafiles ${ }^{1,2}$, and Gina R. Dedeles ${ }^{1,2^{*}}$
}

\begin{abstract}
Thraustochytrids are marine protists that can be abundantly found on fallen mangrove leaves. These organisms are drawing attention from scientists and commercial manufacturers alike primarily because they are able to produce omega-3 polyunsaturated fatty acids (PUFA) such as docosahexaenoic acid (DHA) and eicosapentaenoic acid (EPA) in copious amounts within their cells. Scientists from Brazil, Malaysia, Taiwan, and Thailand have capitalized on their country's thraustochytrids; yet, in the Philippines only a limited number of researches have been conducted on these organisms. Thus, the significance of this research is to further investigate, supplement additional information, and add to the number of existing studies on the thraustochytrids from Philippine mangroves. This research isolated, purified, and characterized thraustochytrids present in yellow, yellow brown, and brown leaves from two (2) mangrove species-Avicennia and Rhizophora spp. in Pagbilao Mangrove Forest. The thraustochytrids from each leaf sample of the two mangrove species were isolated and purified on GYPSA (Glucose Yeast Peptone Sea Salt Agar) media. Morphological characterization was done through microscopy for partial identification. The isolates present on fallen mangrove leaves from Pagbilao, Quezon were preliminarily identified as morphologically indicative to either be Aurantiochytrium, Hondaea, or Monorhizochytrium.
\end{abstract}

Keywords: marine protists, heterotrophs, Thraustochytriacae, Philippines

\section{Introduction}

Mangrove ecosystems are one of the most vital ecosystems in tropical countries (Dangan-Galon et al., 2016; Gevaña et al., 2019). They are considered as a link between terrestrial and marine life, forming the base of numerous marine food sources since they transfer organic matter and energy from land to sea (Gevaña et al., 2019; Lee et al., 2014; Nagelkerken et al., 2008). In mangrove habitats, there are many species of microorganisms that thrive, and one of these are the thraustochytrids (Leaño, 2001; Phuphumirat et al., 2016; Raghukumar et al., 1994; Saravanakumar et al., 2016).

These heterotrophic eukaryotes belong to the Thraustochytriacae of the Straminipila (Dick, 2001; Bennett et

${ }^{1}$ Department of Biological Sciences, College of Science, University of
Santo Tomas, Manila
${ }^{2}$ Research Center for the Natural and Applied Sciences, University of
Santo Tomas, Manila
*Corresponding email: grdedeles@ust.edu.ph
Date Submitted: 26 August 2019
Date Accepted: 27 May 2020

(C) Association of Systematic Biologists of the Philippines al., 2017; Marchan et al., 2018; Tsui et al., 2009). They are easily found in mangrove detritus because of the substrates' contact with brackish water, containing trace minerals required for their survival, along with rich organic material (Fan et al., 2002; Nagano et al., 2013; Raghukumar, 2002; Raghukumar et al., 1994; Saravanakumar et al., 2016; Shabala et al., 2009; Ueda et al., 2015; Wong et al., 2005). Moreover, they have also been observed to be just as abundantly associated in organic material in marine environments (Naganuma et al., 1998; Ramaiah et al., 2005; Sharma et al., 1994). Their reproduction and nutrient scavenging occur through the production of ectoplasmic nets (that may be very pronounced in some species), biflagellated zoospores and/or amoeboid cells (Bennett et al., 2017; Dellero et al., 2018; Iwata \& Honda, 2018; Raghukumar, 2002; Yokoyama \& Honda, 2007).

For about two decades now, they have consistently drawn attention from scientists due to their ability to produce large amounts of fatty acids, which may be of benefit to human and animal development as well as well-being maintenance (Arafiles et al., 2011, 2014; Fan et al., 2007; Furlan et al., 2017; Huang et al., 2001; Leaño \& Liao, 2004; Raghukumar, 2008; Singh et al., 2016; Yamasaki et al., 2006). Examples of these fatty acids are the polyunsaturated fatty acids (PUFA), which are traditionally 
sourced from deep ocean fish like tuna. With threats to global fish populations, research has consistently veered towards single-cell sources of PUFA such as the thraustochytrids to provide for demands in the nutritional supplement and aquaculture industries (Béligon et al., 2016; Gupta et al., 2012). Even researchers from temperate countries such as Australia, Canada and Japan have placed great efforts in studying thraustochytrids. (Aki et al., 2003; Furlan et al., 2017; Huang et al., 2001; Singh et al., 2016; Ugalde et al., 2018; Yamasaki et al., 2006). Despite the rich mangrove habitats in the Philippines, there are but a handful of researches conducted here (Arafiles $e t$ al., 2011; Atienza et al., 2012; Dela Peña et al., 2016; EstudilloCastillo et al., 2009; Leaño, 2001; Leaño et al., 2003; Ludevese -Pascual et al., 2016; Oclarit \& Hepowit, 2007; Uba et al., 2016). This research further investigates, supplements additional information, and adds to the number of researches on thraustochytrids in the country.

This study aims to characterize the morphological features, and to provide a partial identification of the species of thraustochytrids present in different colors on the leaves of Avicennia and Rhizophora spp. mangrove trees in Pagbilao Mangrove Forest, Quezon.

\section{Materials and Methods}

\section{Sampling, Collection, and Media Preparation}

Leaf samples (yellow, yellow brown, and brown) from Avicennia spp. (local name "bungalon") and Rhizophora spp. (local name "bakauan lalaki") were collected from Pagbilao, Quezon $\left(13.9753^{\circ} \mathrm{N}, 121.7255^{\circ} \mathrm{E}\right)$ in February 2019 when temperatures ranged between $25-32^{\circ} \mathrm{C}$. In particular, yellow, yellow-brown and brown leaves were chosen because they were expected to be in advanced stages of decay. Raghukumar et al. (1994) determined that detritus aged $>21 \mathrm{~d}$ old harbored more cells of the thraustochytrid Aurantiochytrium mangrovei than those $<21 \mathrm{~d}$ old. Since more fungi and oomycetes are also expected to be present in freshly fallen leaves, leaves that had already turned yellow or brown were preferred over green ones (Raghukumar et al., 1994; Saravanakumar et al., 2016; Wong et al., 2005)

Leaf samples were placed in a resealable plastic bag halfway filled with seawater, stored in an icebox, and brought to the Laboratory of Pure and Applied Microbiology (PAM) at the Thomas Aquinas Research Complex (TARC), University of Santo Tomas for processing.

Glucose-Yeast-Peptone-Seawater Agar (GYPSA) composed of $0.3 \%$ glucose, $1.25 \mathrm{~g}$ yeast, $1.25 \mathrm{~g}$ peptone, $15 \mathrm{~g}$ agar, $50 \%$ seawater (salinity $=\sim 18 \mathrm{ppt}$ ), and $50 \%$ distilled water, was used in the experiment. In order to inhibit the growth of contaminants, $250 \mathrm{mg} / \mathrm{L}$-medium of streptomycin and penicillin, and nystatin were added (Leaño, 2001).

\section{Isolation, Purification, and Characterization}

The leaves were initially washed with running tap water to remove attached debris. Leaves were cut into $15-\mathrm{mm}$ wide strips and washed in $50 \%$ sterile seawater three times with an interval of $1 \mathrm{~h}$ between washes (Fan \& Kamlangdee, 2003). The leaves were blot-dried on tissue paper and placed on the GYPSA media. A drop of $50 \% \mathrm{SSW}$ was placed on the side of each leaf to promote primary sporulation of the thraustochytrids. The plates were incubated at room temperature $\left(\sim 30^{\circ} \mathrm{C}\right)$ for $24-48 \mathrm{~h}$. The periphery and the bottom surface of the leaves that were in direct contact with the agar were checked for colonies of the organism (Leaño et al., 2003). Colonies were picked with an inoculating loop and then subcultured and purified on GYPSA agar. Pure thraustochytrid cultures were incubated for 3-4 d and were characterized by microscopy.

\section{Results and Discussion}

Twelve (12) thraustochytrid isolates were isolated from mangrove leaves in Pagbilao Mangrove Park. Their colony morphologies were observed after culturing on GYPSA and revealed white to pale orange colonies (Figure 1). Despite being sampled from fallen leaves of different trees, the appearance of their colony forms, elevation, surface and opacity were similar. However, there were two isolates (RY-2, RB-1) from leaves of Rhizophora sp. that formed undulate margins (Table 1).

Although most of the isolates appeared white to creamcolored, it is worthwhile to mention that $25 \%$ of all the isolates have somewhat pale orange appearance, which may signify carotenoid or xanthophyll production (Aki et al., 2003; Atienza et al., 2012). Thus far, there has only been one report of carotenoids in Philippine thraustochytrids (Atienza et al., 2012). This study, therefore, can be an encouraging new starting point for those interested in studying about carotenogenous Philippine thraustochytrids and their prevalence in the country.

Micrographs of the cell morphology and mode of reproduction of all isolates are presented in Figures $2 \& 3$. All isolates had a circular cell shape ranging between $12-20 \mu \mathrm{m}$ in diameter (Figure 2). The cells slightly glistened green, which is indicative of their oleaginous nature. The cells exhibited partitioning from a central point, rather than the release of amoeboid or zoosporic cells; moreover, their ectoplasmic nets were also inconspicuous. These observations along with that of the colonial features pointed to the morphologically similar genera Aurantiochytrium, Hondaea or Monorhizochytrium as a 


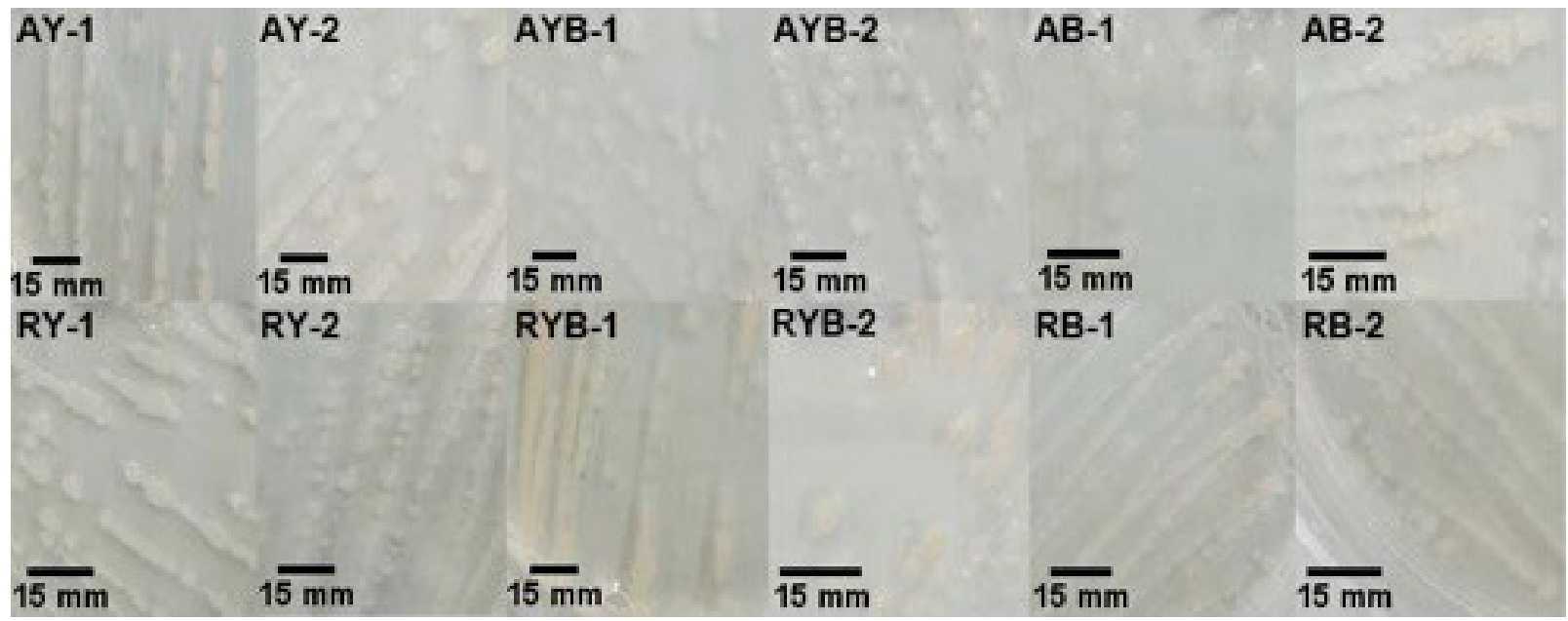

Figure 1. Colony appearance and size of thraustochytrids isolated from fallen leaves of Avicennia sp. (top) and Rhizophora sp. (bottom)

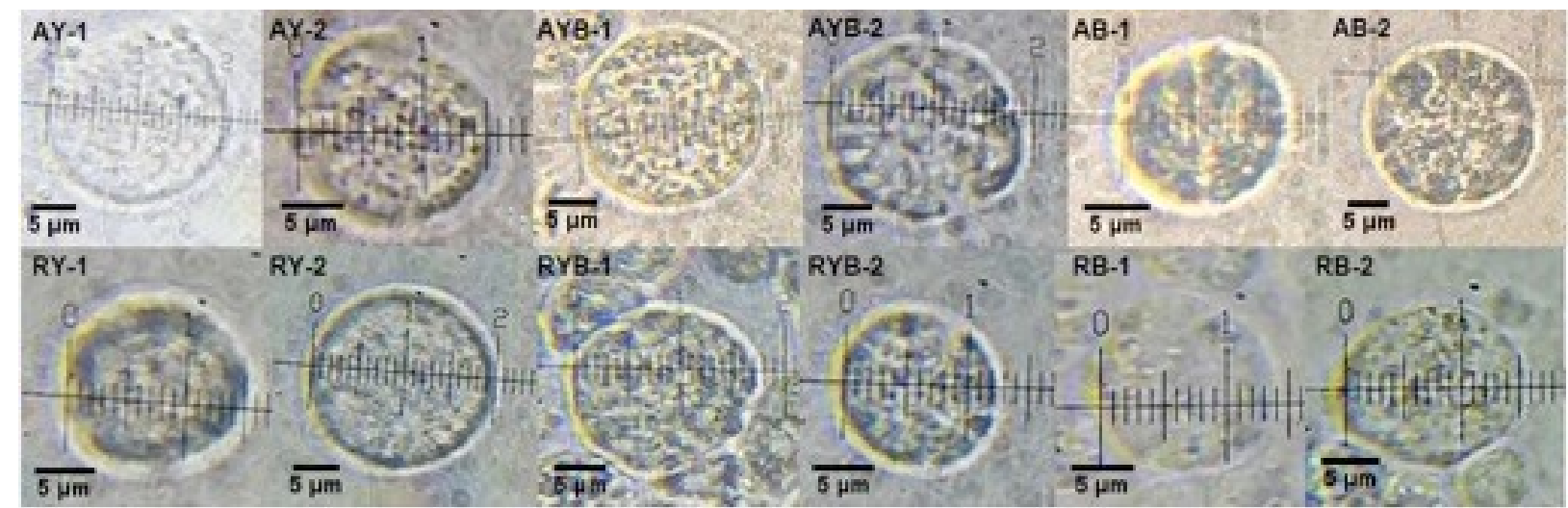

Figure 2. Cell size of thraustochytrids isolated from fallen leaves of Avicennia sp. (top) and Rhizophora sp. (bottom). Magnification: 100x

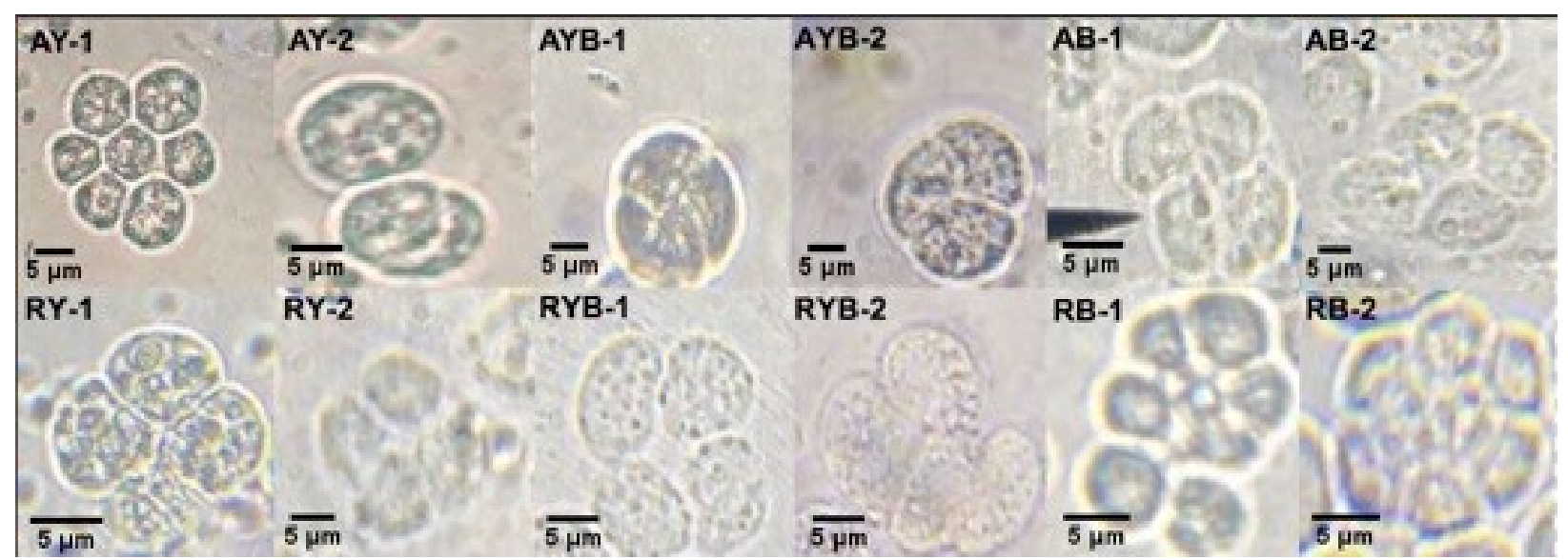

Figure 3. Cell morphological features of thraustochytrids isolated from fallen leaves of Avicennia sp. (top) and Rhizophora sp. (bottom). Magnification: 100x 
Table 1. Description of colony morphologies of thraustochytrids isolated from fallen leaves of decayingAvicennia sp. and Rhizophora sp. leaves

\begin{tabular}{|c|c|c|c|c|c|c|c|c|}
\hline \multirow{2}{*}{$\begin{array}{c}\text { Leaf } \\
\text { species }\end{array}$} & \multirow{2}{*}{ Leaf color } & \multirow{2}{*}{$\begin{array}{l}\text { Isolate } \\
\text { code }\end{array}$} & \multicolumn{6}{|c|}{ Colony description } \\
\hline & & & Form & Elevation & Margin & Surface & Opacity & Color \\
\hline \multirow{8}{*}{ Avicennia } & \multirow{3}{*}{ Yellow } & AY-1 & Circular & Flat & Entire & Glistening & Opaque & $\begin{array}{c}\text { Pale } \\
\text { orange }\end{array}$ \\
\hline & & & & & & & & \\
\hline & & AY -2 & Circular & Flat & Entire & Glistening & Opaque & White \\
\hline & \multirow{2}{*}{$\begin{array}{l}\text { Yellow } \\
\text { brown }\end{array}$} & AYB-1 & Circular & Flat & Entire & Glistening & Opaque & White \\
\hline & & AYB-2 & Circular & Flat & Entire & Glistening & Opaque & White \\
\hline & \multirow{3}{*}{ Brown } & AB-1 & Circular & Flat & Entire & Glistening & Opaque & White \\
\hline & & & & & & & & \\
\hline & & AB-2 & Circular & Flat & Entire & Glistening & Opaque & White \\
\hline \multirow{7}{*}{ Rhizophora } & \multirow{3}{*}{ Yellow } & RY-1 & Circular & Flat & Entire & Glistening & Opaque & White \\
\hline & & & & & & & & \\
\hline & & RY-2 & Circular & Flat & Undulate & Glistening & Opaque & White \\
\hline & \multirow{2}{*}{$\begin{array}{l}\text { Yellow } \\
\text { brown }\end{array}$} & RYB-1 & Circular & Flat & Entire & Glistening & Opaque & $\begin{array}{c}\text { Pale } \\
\text { orange }\end{array}$ \\
\hline & & RYB-2 & Circular & Flat & Entire & Glistening & Opaque & $\begin{array}{l}\text { Pale } \\
\text { orange }\end{array}$ \\
\hline & \multirow[b]{2}{*}{ Brown } & RB-1 & Circular & Flat & Undulate & Glistening & Opaque & $\begin{array}{c}\text { White to } \\
\text { pale } \\
\text { orange }\end{array}$ \\
\hline & & RB-2 & Circular & Flat & Entire & Glistening & Opaque & $\begin{array}{c}\text { White to } \\
\text { pale } \\
\text { orange }\end{array}$ \\
\hline
\end{tabular}


highly possible classification of the 12 isolates (Dellero et al., 2018; Doi \& Honda, 2017; Yokoyama \& Honda, 2007).

Aurantiochytrium possesses a globose thallus with a thin wall and underdeveloped ectoplasmic net. Cell diameters range from 10-20 $\mu \mathrm{m}$ and undergo continuous bipartitioning. Colonies are off-white in color and became pale-orange upon prolonged incubation due to the presence of carotenoids (Ganuza et al., 2019; Yokoyama \& Honda, 2007) Hondaea and Monorhizochytrium are also similar morphologically to Aurantiochytrium and have been classified together by Dellero et al. (2018) as a superclade within the Thraustochytriacae due to their $18 \mathrm{~S}$ rRNA sequences having more than $97 \%$ similarity to each other.

Aurantiochytrium is indisputably the most studied among the thraustochytrids for their great promise as fatty acid and carotenoid producers for industries (Aasen et al., 2016; Aki et al., 2003; Arafiles et al., 2014; Furlan et al., 2017; Yamasaki et al., 2006). However, the recently isolated Hondaea fermentalgiana from the Indian Ocean is expected to be a promising source of sterol production based on pathway mapping (Dellero et al., 2018). To conclusively point the identity of the 12 isolates to a particular genus, more data composed of chemotaxonomic features and 18S rRNA sequences will be necessary.

Yet with the morphologically similar isolates found in this study, this is no assurance that the environment of Pagbilao Mangrove Park only harbors this group of genetically similar thraustochytrids. There are thraustochytrids such as Oblongochytrium that are known to be most abundant in ecosystems but are unable to grow well in agar media (Ueda $e t$ al., 2015). This genus is characterized by thin-walled, globose, pale yellow thalli and well-developed ectoplasmic nets (Yokoyama \& Honda, 2007; Ganuza et al., 2019). A close taxonomic relative of the thraustochytrids, the labyrinthulids, have exhibited the use of their ectoplasmic nets to forage on diatoms for nutrition (Hamamoto \& Honda, 2019). The strains in this study may have unwittingly been given an advantage over oligotrophic thraustochytrids due to the culture media and conditions provided. For all the Thraustochytriacae to be detected and well-represented, non-culture-based methods will have to be employed and are strongly recommended for future thraustochytrid diversity research.

\section{Conclusion and Recommendations}

Twelve (12) thraustochytrid isolates from fallen mangrove leaves in Pagbilao Mangrove Park, Quezon were identified as possible members of the genera Aurantiochytrium, Hondaea or Monorhizochytrium.
All isolates appeared similar; thraustochytrids were also present in all the leaf samples despite the latter in different states of degradation as indicated by their color. Since this study has only employed colonial and microscopic observations to identify the isolates, it is highly recommended to subject the isolates to $18 \mathrm{~S}$ rRNA sequencing to fully determine their identity to the species level and to de-replicate isolates, if possible. Their fatty acid and carotenoid compositions can also be characterized along with further observations of their zoospore size, shape, counts and formation/release process. There were promising isolates that appeared pale orange to the naked eye. Thus, these isolates may warrant further study by microbial biotechnologists for possible industrial applications.

\section{Acknowledgements}

The researchers would like to thank the Research Center for the Natural and Applied Sciences (RCNAS) of the University of Santo Tomas, as well as Gel Anne Marie V. Atienza, Ma. Criselda M. Carmona and Reuel M. Bennett for their insights. This study was also completed through the project of Dr. Dedeles with assistance from the National Research Council of the Philippines' (NRCP) project number 007.

\section{Author Contributions}

J.G. Perez, A.K. Mappala, C.K. Icaro \& A.M. Estrada conducted the leaf sampling, thraustochytrid isolation, results documentation and writing of the initial versions of this manuscript. K.H. Arafiles \& G.R. Dedeles contributed to later versions and proofread this manuscript.

\section{Literature Cited}

Aasen, I.M., H. Ertesvag, T.M.B. Heggeset, B. Liu, T. Brautaset, O. Vadstein \& T.E. Ellingsen, 2016. Thraustochytrids as production organisms for docosahexaenoic acid (DHA), squalene, and carotenoids. Applied Microbiology and Biotechnology, 100(10): 43094321.

Aki, T., K. Hachida, M. Yoshinaga, Y. Katai, T. Yamasaki, S. Kawamoto, T. Kakizono, T. Maoka, S. Shigeta, O. Suzuki $\&$ K. Ono, 2003. Thraustochytrid as a potential source of carotenoids. Journal of the American Oil Chemists' Society, 80: 789-794.

Arafiles, K.H., H. Iwasaka, Y. Eramoto, Y. Okamura, T. Tajima, Y. Matsumura, Y. Nakashimada \& T. Aki, 2014. Valueadded lipid production from brown seaweed biomass by two-stage fermentation using acetic acid bacterium and 
thraustochytrid. Applied Microbiology and Biotechnology, 98: 9207-9216.

Arafiles K.H.V., J.C.O. Alcantara, J.A.L. Batoon., F.S. Galura, P.R.F. Cordero, E.M. Leaño \& G.R. Dedeles, 2011. Cultural optimization of thraustochytrids for biomass and fatty acid production. Mycosphere, 2(5): 521-531.

Atienza, G.M.A., K.H.V. Arafiles, M.C.M. Carmona, J.P.C. Garcia, A.M.B. Macabago, B.J.D.C. Peñacerrada, P.R.F. Cordero, R.M. Bennett \& G.R. Dedeles, 2012. Carotenoid analysis of locally isolated thraustochytrids and their potential as an alternative fish feed for Oreochromis niloticus (Nile tilapia). Mycosphere, 3(4): 420-428.

Béligon, V., G. Christophe, P. Fontanille \& C. Larroche, 2016. Microbial lipids as potential source to food supplements. Current Opinion in Food Science, 7: 35-42.

Bennett, R.M., D. Honda, G.W. Beakes \& M. Thines, 2017. Labyrinthulomycota. In: Archibald, J.M., A.G.B. Simpson \& C.H. Slamovits (eds.), Handbook of the Protists. Springer International Publishing AG, Cham, Switzerland. pp. 509-534.

Dangan-Galon, F., R.G. Dolorosa, J.S. Sespeñe \& N.I. Mendoza. 2016. Diversity structural complexity of mangrove forest along Puerto Princesa Bay, Palawan Island, Philippines. Journal of Marine and Island Cultures, 5: $118-125$.

De la Peña, M.R., M.B. Teruel, J.M. Oclarit, M.J.A. Amar \& E.G.T. Ledesma, 2016. Use of thraustochytrid Schizochytrium sp. as source of lipid and fatty acid in a formulated diet for abalone Haliotis asinina (Linnaeus) juveniles. Aquaculture International, 24: 1103-1118.

Dellero, Y., O. Cagnac, S. Rose, K. Seddiki, M. Cussac, C. Morabito \& A. Amato, 2018. Proposal of a new thraustochytrid genus Hondaea gen. nov. and comparison of its lipid dynamics with the closely related pseudo-cryptic genus Aurantiochytrium. Algal Research, 35: 125-141.

Dick, M.W., 2001. Straminipilous Fungi: Systematics of the Peronosporomycetes Including Accounts of the Marine Straminipilous Protists, the Plasmodiophorids and Similar Organisms. Kluwer Academic Publishers, Dordrecht, The Netherlands. 670 pp.

Doi, K. \& D. Honda, 2017. Proposal of Monorhizochytrium globosum gen. nov., comb. nov. (Stramenopiles, Labyrinthulomycetes) for former Thraustochytrium globosum based on morphological features and phylogenetic relationships. Phycological Research, 65: 188 -201 .

Estudillo-del Castillo, C., Gapasin, R.S. \& Leaño, E.M., 2009. Enrichment potential of HUFA-rich thraustochytrid
Schizochytrium mangrovei for the rotifer Brachionus plicatilis. Aquaculture, 293: 57-61.

Fan, K.W. \& N. Kamlangdee, 2003. Polyunsaturated fatty acids production by Schizochytrium sp. isolated from mangrove. Journal of Science and Technology, 25: 643-650.

Fan, K., Y. Jiang, Y. Fan \& F. Chen, 2007. Lipid characterization of mangrove thraustochytridSchizochytrium mangrovei. Journal of Agricultural and Food Chemistry, 55: 2906-2910.

Fan, K.W., L.L.P. Vrijmoed \& E.B.G. Jones, 2002. Physiological studies of subtropical mangrove thraustochytrids. Botanica Marina, 45: 50-57.

Furlan, V.J.M., V. Maus, I. Batista \& N.M. Bandarra, 2017. Production of docosahexaenoic acid by Aurantiochytrium sp. ATCC PRA-276. Brazilian Journal of Microbiology, 48: 359-365.

Ganuza, E., S. Yang, M. Amezquita, A. Giraldo-Silva \& R.A. Andersen, 2019. Genomics, biology and phylogeny of Aurantiochytrium acetophilum sp. nov. (Thraustrochytriaceae), including first evidence of sexual reproduction. Protist, 170: 209-232.

Gevaña, D.T., J.M Pulhin \& M.A. Tapia, 2019. Fostering Climate Change Mitigation Through a Community-based Approach: Carbon Stock Potential of Community-managed Mangroves in the Philippines. In: Krishnamurthy, R.R., M.P. Jonathan, S. Srinivasalu \& B. Glaeser (eds.), Coastal Management: Global Challenges and Innovations. Academic Press, London. pp. 271-282.

Gupta, A., C.J. Barrow, \& M. Puri, 2012. Omega-3 biotechnology: Thraustochytrids as a novel source of omega -3 oils. Biotechnology Advances, 30: 1733-1745.

Hamamoto, Y. \& D. Honda, 2019. Nutritional intake of Aplanochytrium (Labyrinthulea, Stramenopiles) from living diatoms revealed by culture experiments suggesting the new prey-predator interactions in the grazing food web of the marine ecosystem. PLos One, 14(1): e0208941.

Huang, J., T. Aki, K. Hachida, T. Yokochi, S. Kawamoto, S. Shigeta, K. Ono \& O. Suzuki, 2001. Profile of polyunsaturated fatty acids produced by Thraustochytrium sp. KK17-3. Journal of the American Oil Chemists' Society, 78(6): 605-610.

Iwata I. \& D. Honda, 2018. Nutritional intake by ectoplasmic nets of Schizochytrium aggregatum (Labyrinthulomycetes, Stramenopiles). Protist, 169: 727-743.

Leaño, E.M., 2001. Straminipilous organisms from fallen mangrove leaves from Panay Island, Philippines. Fungal Diversity, 6: 75-81. 
Leaño, E.M. \& L.C. Liao, 2004. Thraustochytrids: potential DHA source for marine fish nutrition. Global Aquaculture Advocate, 7: 87-88.

Leaño, E.M., R.S.J. Gapasin, B. Polohan \& L.L.P. Vrijmoed, 2003. Growth and fatty acid production of thraustochytrids from Panay mangroves, Philippines. Fungal Diversity, 12: 111- 122.

Lee, S.Y., J.H. Primavera, F. Dahdouh-Guebas, K. Mckee, J.O. Bosire, S. Cannicci, K. Diele, F. Fromard, N. Koedam, C. Marchand, I. Mendelssohn, N. Mukherjee \& S. Record, 2014. Ecological role and services of tropical mangrove ecosystems: a reassessment. Global Ecological and Biogeography, 23: 726-743.

Ludevese-Pascual, G., M. De la Peña \& J. Tornalejo, 2016. Biomass production, proximate composition and fatty acid profile of the local marine thraustochytrid isolate, Schizochytrium sp. LEY7 using low-cost substrates at optimum culture conditions. Aquaculture Research, 47: 318 -328 .

Marchan, L.R., K. Change, P. Nichols, W. Mitchell, J. Polglase \& T. Gutierrez, 2018. Taxonomy, ecology and biotechnological applications of thraustochytrids: A review. Biotechnology Advances, 36: 26-46.

Nagano, N., Y. Taoka, D. Honda, \& M. Hayashi, 2013. Effect of trace elements on growth of marine eukaryotes, thraustochytrids. Journal of Bioscience and Bioengineering, 116: 337-339.

Naganuma, T., H. Takasugi \& H. Kimura, 1998. Abundance of thraustochytrids in coastal plankton. Marine Ecology Progress Series, 162: 105-110.

Nagelkerken, I., S.J.M. Blaber, S. Bouillon, P. Green, M. Haywood, L.G. Kirton, J.O. Meynecke, J. Paqlik, H.M. Penrose, A. Sasekumar \& P.J. Somerfield, 2008. The habitat function of mangroves for terrestrial and marine fauna: A review. Aquatic Botany, 89: 155-185.

Oclarit, J.M. \& Hepowit, N.L., 2007. DNA amplicons using arbitrary primers distinguish polymorphic loci among mangrove thraustochytrid genomes. In: OCEANS 2007 Europe, Institute of Electrical and Electronics Engineers, Piscataway, NJ. pp. 1-7.

Phuphumirat, W., D.K. Ferguson \& Gleason, F.H., 2016. The colonization of palynomorphs by chytrids and thraustochytrids during pre-depositional taphonomic processes in tropical mangrove ecosystems. Fungal Ecology, 23: 11-19.

Raghukumar, S., 2008. Thraustochytrid marine protists: Production of PUFA and other emerging technologies. Marine Biotechnology, 10(6): 631-640.
Raghukumar, S., 2002. Ecology of the marine protists, the Labyrinthulomycetes (Thraustochytrids and Labyrinthulids). European Journal of Protistology, 38: 127145.

Raghukumar, S., S. Sharma, C. Raghukumar \& V. Sathe-Pathak, 1994. Thraustochytrid and fungal component of marine detritus. IV. Laboratory studies on decomposition of leaves of the mangrove Rhizophora apiculata Blume. Journal of Experimental Marine Biology and Ecology, 183:113-131.

Ramaiah, N., S. Raghukumar, G. Mangesh \& M. Madhupratap, 2005. Seasonal variations in carbon biomass of bacteria, thraustochytrids and microzooplankton in the northern Arabian Sea. Deep Sea Research Part II: Topical Studies in Oceanography, 52: 1910-1921.

Saravanakumar, K., R. Anburaj, V. Gomathi \& K. Kathiresan, 2016. Ecology of soil microbes in a tropical mangrove forest of south east coast of India. Biocatalysis and Agricultural Biotechnology, 8: 73-85.

Shabala, L., T. McMeekin \& S. Shabala, 2009. Osmotic adjustment and requirement for sodium in marine protist thraustochytrid. Environmental Microbiology, 11: 18351843.

Sharma S., C. Raghukumar, S. Raghukumar, V. Sathe-pathak \& D. Chandramohan, 1994. Thraustochytrid and fungal component of marine detritus II. Laboratory studies on decomposition of the brown alga Sargassum cinereum J. Ag. Journal of Experimental Marine Biology and Ecology, 175: 227-242

Singh, D., C.J. Barrow, M. Puri, D.K. Tuli \& A.S. Mathur, 2016. Combination of calcium and magnesium ions prevents substrate inhibition and promotes biomass and lipid production in thraustochytrids under higher glycerol concentration. Algal Research, 15: 202-209

Tsui, C.K.M., W. Marshall, R. Yokoyama, D. Honda, J.C. Lippmeier, K.D. Craven, P.D. Peterson \& M. L. Berbee, 2009. Labyrinthulomycetes phylogeny and its implications for the evolutionary loss of chloroplasts and gain of ectoplasmic gliding. Molecular Phylogenetics and Evolution, 50: 129-140.

Uba, M., K.C. Duabe, M.A.C. Biene, M.K.C.R. Ortiz, R.M. Bennett \& G.R. Dedeles, 2016. Growth and fatty acid profile of Thraustochytrium sp. CR01 using different sugar substitutes. Philippine Journal of Science, 145: 365-371.

Ueda, M., Y. Nomura, K. Doi, M. Nakajima \& D. Honda, 2015. Seasonal dynamics of culturable thraustochytrids (Labyrinthulomycetes, Stramenopiles) in estuarine and coastal waters. Aquatic Microbial Ecology, 74: 187-204. 
Ugalde, V., R.E. Armenta, A. Kermanshahi-pour, Z. Sun, K.T. Berryman \& M.S. Brooks, 2018. Improvement of culture conditions for cell biomass and fatty acid production by marine thraustochytrid F24-2. Journal of Applied Phycology, 30: 329-339.

Wong, M.K.M., L.L.P. Vrijmoed \& D.W.T. Au, 2005. Abundance of thraustochytrids on fallen decaying leaves of Kandelia candel and mangrove sediments in Futian National Nature Reserve, China. Botanica Marina, 48: 374378.

Yamasaki, T., T. Aki, M. Shinozaki, M. Taguchi, S. Kawamoto \& K. Ono, 2006. Utilization of Shochu distillery wastewater for production of polyunsaturated fatty acids and xanthophylls using thraustochytrid. Journal of Bioscience and Bioengineering, 102: 323-327.

Yokoyama, R. \& D. Honda, 2007. Taxonomic rearrangement of the genus Schizochytrium sensu lato based on morphology, chemotaxonomic characteristics, and 18S rRNA gene phylogeny (Thraustochytriaceae, Labyrinthulomycetes): emendation for Schizochytrium and erection of Aurantiochytrium and Oblongichytrium gen. nov. Mycoscience, 48: 199-211. 